\title{
La bête humaine DVD
}

\author{
By Jan Uhde
}

\section{Spring 2006 Issue of KINEMA}

The phenomenal growth of the DVD medium is seen by many as an excellent opportunity to bring important films of the present and past to audiences worldwide. Among the anxiously awaited issues, long overdue, has been Jean Renoir's 1938 masterpiece La bête humaine, adopted from the eponymous novel by Emile Zola. Set in the closely-knit community of Le Havre's cheminots, or railwaymen, this major work of the French pre-war poetic realism focuses on the gentle engineer Lantier (Jean Gabin) and his tragic struggle with hereditary insanity. The past haunts other characters of the story as well, especially the abused Sévérine (Simone Simon) who, like Thomas Hardy's Tess, is unable to escape her socially pre-determined fateful trajectory.

Renoir's realistic mise-en-scène, exemplified through his brilliant introductory credit-title sequence, unusual for the 1930s style, influenced the French nouvelle vague two decades later. The director's editing mastery is matched by Gabin's unforgettable understated performance.

Criterion delivered the goods everyone was waiting for so long: an uncensored edition in a new, restored high-definition transfer, Jean Renoir's personal introduction to the film, interview with Director Peter Bogdanovich, archival footage with Simone Simon, interviews with Jean Renoir, Zola scholar Henri Mitterand, photographs, theatrical trailer, and a 38-page booklet.

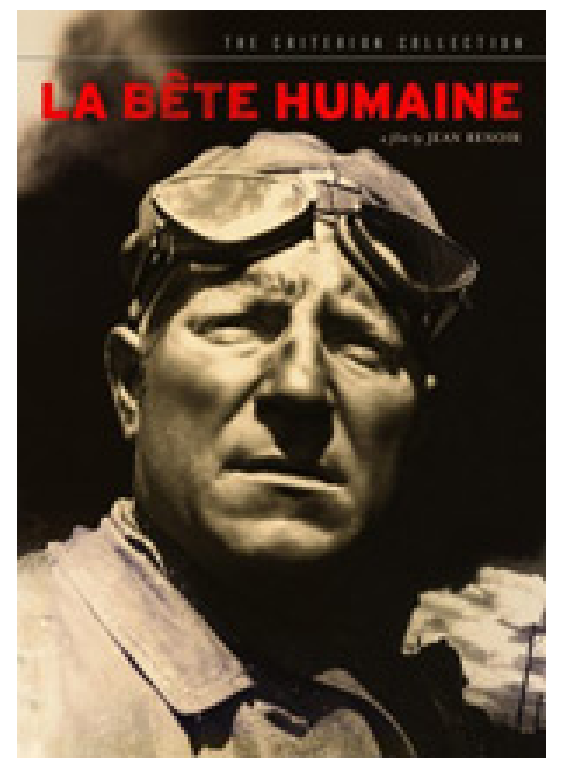

Figure 1: LA B $\hat{E} \boldsymbol{T E} \boldsymbol{H U M A I N E}$ DVD (Jean Renoir, 1938.) NTSC, R-1, DVD-9. Criterion Collection. Subtitled. 38pp booklet. USD 29.95 (discounts).

\section{Author Information}

Jan UHDE is Professor Emer. (Film Studies) at the University of Waterloo, Ontario, Canada. Born in Brno, Czech Republic. Graduated (MA) from the Faculty of Arts, Masaryk University, Brno; PhD received at the University of Waterloo, Ontario, Canada. He taught at the University of Waterloo (1970-2012) where he founded a General and Honours BA program in Film Studies at the Department of Fine Arts.

Publications: Latent Images: Film in Singapore Second edition, with Yvonne Ng Uhde (Ridge Books, National University Press of Singapore, 2010); Latent Images: Film in Singapore, with Yvonne Ng Uhde (Oxford 
University Press, 2000); Latent Images: Film in Singapore CD-ROM (2003, co-author); Vision and Persistence: Twenty Years of the Ontario Film Institute (University of Waterloo Press, 1990) and Ontario Film Institute Programming Activities Index 1969-1989 (Toronto: Ontario Science Centre, 1990). He co-edited the Place in Space: Human Culture in Landscape (Proceedings from the Second International Conference of the Working Group "Culture and Landscape" of the International Association of Landscape Ecology, Pudoc Scientific Publishers, Wageningen, Holland, 1993). Jan Uhde has published articles and reviews in several countries (including Canada, USA, Germany, Italy), participated in international juries at film festivals and presented papers at international conferences in North America and Europe. In 1998/99, he was a visiting researcher at the School for Film and Media Studies, Ngee Ann Polytechnic, Singapore.

His professional and research interests focus on Singapore cinema; the identification and distancing mechanisms of the film viewer; the non-authored modifications and manipulation of films; and specific aspects of film history, including the Central European cinema.

He founded KINEMA in 1993. 